\title{
RENTABILITAS DAN PENYERAPAN TENAGA KERJA AGROINDUSTRI TEH CELUP DAUN KELOR \\ (Studi Kasus di Desa Ciheras Kecamatan Cipatujah Kabupaten Tasikmalaya)
}

\author{
ISMATUL ALAWIAH ${ }^{1 *}$, DINI ROCHDIANI ${ }^{2}$, DANI LUKMAN HAKIM ${ }^{1}$ \\ ${ }^{1}$ Fakultas Pertanian Universitas Galuh \\ ${ }^{2}$ Fakultas Pertanian Universitas Padjajaran \\ *E-mail : ismaciamis01@gmail.com
}

\begin{abstract}
ABSTRAK
Teh merupakan minuman yang dikonsumsi secara umum di masyarakat khususnya masyarakat indonesia. Dalam pembuatan teh daun kelor bermanfaat untuk kesehatan karena mengandung flavonoid sebagai antioksidan dan antiinflamasi. Penelitian ini bertujuan untuk mengetahui besarnya biaya, Penerimaan,pendapatan,rentabilitas dan penyerapan tenaga kerja. Metode yang digunakan yaitu studi kasus dan penarikan responden dilakukan dengan sengaja atau porposive sampling. Hasil dan pembahasan menunjukan bahwa 1) besarnya biaya yang dikeluarkan PT. Lentra Bumi Nusantara pada agroindustri teh celup daun kelor dalam satu kali proses produksi adalah sebesar Rp 3.048.816.besarnya penerimaan yang diperoleh sebesar Rp 5.500,000 , besarnya pendapatan pada agroindustri teh celup daun kelor adalah sebsesar Rp 2.451.183,95.- 2) besarnya niai rentabilitas agroindustri teh celup daun kelor di Desa Ciheras Kecamatan cipatujah adalah 80,40\%, 3) jumlah tenaga kerja yang diserap pada agroindustri teh celup daun kelor dari lingkungan Desa Ciheras dalam satu kali proses produksi adalah sebanyak 6 orang dengan penyerapan tenag kerja sebesar $0,18 \%$.
\end{abstract}

Kata Kunci : Daun Kelor , Penyerapan Tenaga Kerja, Rentabilitas.

\section{ABSTRACT}

Tea is a beverage that is consumed in general in the community,especially the indonesian people. In making moringa leaf tea is beneficial for health because it contains flavonoid as antioxidants and anti-inflammatory. This study aims to determine the amount of costs, revenues, income, rentability and employment. The method used is case studies and the withdrawal of respondents carried out deliberately or porposive sampling. The results showed that: 1) the cost of a teabag agroindustri of moringa leaves at PT. Lentera Bumi Nusantara in one production process was Rp 3.048.816.-, the amount of income obtained was Rp 5.500,000, the amount of income was Rp 2.451.183,95.- 2) the value of the profitability of teabag agroindustry leaves in the Village of Ciheras, Cipatujah Subdistrict was 80,40\% 3) the amount of labor use in one production process was 6 persons with a labor use levet at $0,18 \%$.

Keyword: Employment, Moringa Leaf, Profitability

\section{PENDAHULUAN}

Tanaman kelor (Moringa oleifera)

dikatakan sebagai World's most valuable

multipurpose trees dan miracle tree

(Small,2012). Seluruh bagian tanaman ini

dapat dimanfaatkan menjadi sesuatu yang

berguna, dimulai dari makanan, obat,

kosmetik, bahkan pemurni air (biji).
Tanaman ini juga dapat tumbuh di berbagai iklim, meskipun termasuk dalam tanaman tropis. Afrika sebagai daerah yang menderita masalah kelaparan, merupakan negara dengan iklim yang tidak bersahabat dengan pertanian atau perkebunan. Akan tetapi, pohon ini dapat tumbuh di daerah tersebut dan menjadi salah satu solusi 
inovasi untuk mengurangi berbagai permasalahan disana.

Daun kelor dalam pembuatan teh sangat bermanfaat untuk kesehatan karena mengandung kandungan flavonoid sebagai antioksidan dan antiinflamasi. Menurut Sashidhara, dkk, (2009) beberapa bagian dari kelor digunakan dalam pengobatan penyakit seperti rematik, kelumpuhan dan epilepsi, selain itu ekstrak daun, biji, dan akar dari pohon kelor telah dipelajari secara ekstensif dan analgesik. Kandungan fitokimia dalam daun kelor yaitu tanin, steroid dan triterpenoid, flavonoid, saponin, antraquinon, dan alkaloid. Flavonoid inilah yang mempengaruhi berbagai macam aktivitas biologi atau farmakologi, diantaranya antioksidan, antitumor, antiangiogenik, antialergik dan antiviral (Kasolo, dkk. 2010). Tanaman kelor sudah dikenal luas di Indonesia, khususnya di daerah pedesaan, tetapi belum dimanfaatkan secara maksimal dalam kehidupan sehari-hari. Daun kelor mengandung dua jenis senyawa bioaktif yaitu quercetin dan kaempherol. Antioksidan quercetin termasuk flavonoid dapat mencegah kerusakan sel endotel pada binatang mencit yang terkena aterosklerosis dengan cara menghambat radikal bebas sehingga tidak terbentuk modifikasi LDL menjadi oxy-LDL (Wilcoz dan Subramanian, 1997).

Teh merupakan minuman yang dikonsumsi secara luas dan umum di masyarakat khususnya masyarakat Indonesia. Total produksi teh di Indonesia menurut Direktorat Jenderal Perkebunan (2014) mencapai 143,751 ton pada tahun 2014. Konsumsi teh di Indonesia seperti ditulis oleh Fredman (2014), berdasarkan data dari euromonitor mencapai 1.007 (gram $/ \mathrm{kg}$ ) atau $0.45 \mathrm{~kg}$ per orang setiap tahunnya. Angka ini lebih tinggi dari Switzerland, Ceko, dan Singapura yang tidak mencapai angka 1 (gram $/ \mathrm{kg})$. Teh kaya akan polifenol yang 70\%-nya terdiri dari katekin. EGCG (epigallocatechin-3gallate) merupakan jenis katekin terbanyak yang menyusun total katekin pada teh (Moore, dkk., 2009). EGCG disebutkan memiliki efek kemopreventif dan efek therapeutic yang berpotensi untuk melawan berbagai jenis kanker (Khan, dkk., 2006).

Daun kelor juga mengandung asam amino, antara lain asam amino aspartat, asam glutamat, alanin, valin, leusin, isoleusin, histidin, lisin, arginin, venilalanin, triftopan, sistein dan metionin (Syarifah, dkk., 2015).

Pada pelaksanaan sebuah usaha pasti tidak akan terlepas dari biaya produksi. 
Suratiyah, dkk, (2008) menyatakan, bahwa biaya (Cost) dapat dibedakan menjadi Biaya Tetap (Fixed Cost) yaitu yang besar kecilnya tidak dipengaruhi oleh besar kecilnya produksi (y), dan biaya Variabel (Variabel Cost) yaitu biaya yang besar kecilnya dipengaruhi oleh besar kecilnya produksi.

Menurut Rahim dan Hastuti (2009), penerimaan dapat diketahui dengan mengalikan jumlah produksi total dengan harga produk tersebut dan pendapatan yaitu selisih antara penerimaan dengan semua biaya. Sejalan dengan hal tersebut Soekartawi (2008) menyatakan bahwa pendapatan yaitu selisih antara penerimaan dengan semua biaya yang dikeluarkan dalam melakukan kegiatan usaha, dan R/C merupakan perbandingan penerimaan dengan biaya total.

Rentabilitas perusahaan menunjukkan perbandingan laba dengan aktifa, atau modal untuk menghasilkan laba tersebut. Pengertian rentabilitas adalah kemampuan perusahaan dalam menghasilkan keuntungan dengan semua modal yang bekerja di dalamnya (Harahap, 2008).

Angkatan kerja (labour force) didefinisikan mereka yang mempunyai pekerjaan, baik sedang bekerja maupun yang sementara tidak bekerja, angkatan kerja merupakan bagian dari penduduk yang termasuk ke dalam usia kerja, usia kerja adalah suatu tingkat umur seseorang yang diharapkan sudah dapat bekerja dan menghasilkan pendapatannya sendiri. Jumlah angkatan kerja dalam suatu negara atau suatu daerah, tergantung dari pertumbuhan penduduk usai kerja, berkisar antara 15 sampai 64 tahun. Selain penduduk usia kerja, terdapat penduduk di luar usia kerja, perbandingan antara angkatan kerja dan bukan angkatan kerja disebut tingkat partisipasi kerja (Mulyani, 2010).

Menurut survei lapangan diketahui bahwa di Kecamatan Cipatujah mempunyai 1 unit agroindustri teh celup daun kelor yang berada di Desa Ciheras. Sehubungan dengan hal itu, maka penulis merasa tertarik untuk melaksanakan penelitian mengenai Rentabilitas dan agroindustri teh celup daun kelor yang dilaksanakan pada agroindustri teh celup daun kelor yang merupakan studi kasus di Desa Ciheras Kecamatan Cipatujah Kabupaten Tasikmalaya.

\section{METODE PENELITIAN}

\section{Tempat dan Waktu Penelitian}

Jenis penelitian yang digunakan dalam penelitian ini adalah metode studi kasus dengan mengambil kasus pada agroindustri teh celup daun kelor di Desa 
Ciheras Kecamatan Cipatujah Kabupaten Tasikmalaya. Penarikkan Responden dilakukan dengan sengaja atau porposive sampling pada PT. Lentera Bumi Nusantara, dengan pertimbangan agroindustri tersebut merupakan satusatunya agroindustri Teh Celup Daun Kelor.

Sumber data yang di kumpulkan dalam penelitian ini meliputi data primer dan data sekunder. Data primer diperoleh dari kuesioner yang berkaitan dengan informasi yang ingin diperoleh dari penelitian ini, Data sekunder diperoleh melalui instansi dan departemen yang terkait dengan penelitian, serta melalui penelusuran literatur.

\section{Rancangan Analisis Data}

a. Rancangan Analisis Data

Untuk menentukan besarnya biaya, penerimaan dan pendapatan yang diterima dari agroindustri teh celup daun kelor dapat diketahui dengan menggunakan rumus sebagai berikut :

\section{1) Analisis Biaya}

Untuk mengetahui biaya total (Total Cost) digunakan rumus sebagai berikut (Rahardja dan Manurung, 2008) :

$\mathbf{T C}=\mathbf{T F C}+\mathbf{T V C}$
TC $=$ Total Cost (Biaya Total)

FC = Total Fixed Cost (Biaya Tetap Total)

TVC = Total Variable Cost ( Biaya Variabel Total)

2) Analisis Penerimaan

Untuk mengetahui besarnya penerimaan digunakan rumus sebagai berikut (Rahardja dan Manurung, 2008) :

$$
\mathbf{T R}=\mathbf{Y} \mathbf{x} \mathbf{P y}
$$

Dimana :

$\begin{array}{ll}\text { TR } & \text { Total Revenue } \\ & \text { (Penerimaan Total) } \\ \text { Y } & \text { = Jumlah Produksi } \\ \text { Py } & =\text { Harga }\end{array}$

3) Analisis Pendapatan

Untuk mengetahui besarnya pendapatan digunakan rumus sebagai berikut (Rahardja dan Manurung, 2008) :

$$
\text { Pd }=\text { TR }- \text { TC }
$$

Dimana ;

Pd = Pendapatan

$\mathrm{TR}=$ Total Revenue

(Penerimaan Total)

TC $=$ Total Cost (Biaya Total)

4) Analisis Rentabilitas

Untuk mengetahui besarnya nilai rentabilitas menggunakan rumus sebagai berikut (Rahardja dan Manurung, 2008) :

$\mathbf{R}=\frac{\mathrm{L}}{\mathrm{M}} \times 100 \%$

Dimana : 
Dimana :

$\mathrm{R}=$ Nilai rentabilitas (\%)

$\mathrm{L}=$ Jumlah laba yang diperoleh pada periode tertentu (Rp)

$\mathrm{M}=$ Modal atau biaya yang digunakan Untuk menghasilkan laba tersebut (Rp)

5) Untuk mengetahui tingkat penyerapan tenaga kerja dapat dihitung dengan menggunakan rumus menurut Suratiyah, yaitu :

6)

PTK $=\frac{\text { Jumlah tenaga kerja yang diserap }}{\text { Jumlah angkatan kerja }} \times 100$

\section{HASIL DAN PEMBAHASAN}

Analisis usaha agroindustri teh celup daun kelor melipiti biaya, penerimaan, pendapatan, rentabilitas dan penyerapan tenaga kerja yang dihitung selama satu kali proses produksi. Biaya tetap yang dihitung dalam penelitian ini meliputi pajak bumi bangunan, bunga modal tetap dan penyusutan alat. Hasil penelitian menunjukkan bahwa biaya tetap total yang dikeluarkan dalam agroindustri teh celup daun kelor dalam satu kali proses produksi adalah Rp 105.171,05.-

Biaya variabel total yang dikeluarkan oleh agroindustri teh celup daun kelor, meliputi biaya sarana produksi dan biaya tenaga kerja. Besarnya biaya variabel total yang dikeluarkan oleh agroindustri teh celup daun kelor adalah Rp 2.943.645.- Adapun biaya total yang dikeluarkan merupakan penjumlahan dari biaya tetap dan biaya variabel. Besarnya biaya total yang dikeluarkan untuk agroindustri teh celup daun kelor adalah Rp 3.048.816.- $\quad$ Yang terdiri dari biaya tetap total dan biaya variabel total, proses produksi agroindustri teh celup daun kelor di desa ciheras sudah mampu membiaya keseluruhan biaya produksi yang dikeluarkan dari modal yang dimiliki. Lasut (2015) RM. Ragey Poppy mempunyai kemampuan dalam mendanai setiap aktivitas-aktivitas perusahaan. Capaian ini mengisyaratkan bahwa RM. Ragey Poppy memberikan hasil yang maksimal dan membuka peluang usaha yang baik dimasa yang akan datang.

\section{Analisis Penerimaan dan Pendapatan}

\section{Agroindustri Teh Celup Daun Kelor}

Untuk memperoleh penerimaan dari suatu agroindustri teh celup daun kelor di Desa Ciheras ini dihitung dengan cara mengalikan hasil teh celup daun kelor satu kali proses produksi dengan harga jual saat penelitian dan untuk mengetahui besarnya rata-rata pendapatan atau keuntungan agroindustri teh celup daun kelor di Desa Ciheras diperoleh dengan mengurangi jumlah besarnya penerimaan dengan total biaya produksi. Semaoen (1992) menyatakan dalam ekonomi produksi 
pertanian, asumsi yang lazim digunakan adalah produsen bertujuan memaksimumkan keuntungan, yaitu total penerimaan dikurangi biaya. Petani bertujuan untuk memaksimalkan keuntungan dengan mengalokasikan sumberdaya lahan, tenaga kerja dan peralatan yang dimiliki. Keuntungan itu digunakan untuk memenuhi keinginannya dalam memperoleh barang dan jasa sehingga diperoleh nilai guna atau kepuasan yang tinggi.

Tabel 1. Analisis Usaha, Rentabilitas dan Penyerapan Tenaga Kerja Pada Agroindustri Teh Celup Daun Kelor

\begin{tabular}{|c|c|c|c|}
\hline No & Uraian & Biaya $(\mathbf{R p})$ & Persentase \% \\
\hline \multirow[t]{5}{*}{ A. } & Biaya Tetap & & \\
\hline & 1. $\mathrm{PBB}$ & 520,83 & 0,50 \\
\hline & 2. Penyusutan Alat & $104.126,98$ & 99,00 \\
\hline & 3. Bunga Modal & 523,24 & 0,50 \\
\hline & Biaya Tetap Total & 105.171,05 & 100,00 \\
\hline \multirow[t]{23}{*}{ B. } & Biaya Variabel & & \\
\hline & 1. Saprodi & & \\
\hline & a. Tea Bag & 100.000 & 3,40 \\
\hline & b. Tali Celup Teh & 7.500 & 0,25 \\
\hline & c. Label Besar & 36.000 & 1,22 \\
\hline & d. Label Kecil & 37.500 & 1,27 \\
\hline & e. Masker & 15.000 & 0,51 \\
\hline & f. Sarung Tangan & 30.000 & 1,02 \\
\hline & g. Pouch & 300.000 & 10,19 \\
\hline & h. Gas & 150.000 & 5,10 \\
\hline & i. Listrik & 50.000 & 1,70 \\
\hline & j. Kantong Plastik & 8.000 & 0,27 \\
\hline & k. Karet Gelang & 35.000 & 1,19 \\
\hline & 1. Daun Kelor & 80.000 & 2,72 \\
\hline & 2. Tenaga Kerja & & \\
\hline & a. Pengikatan Tangkai Kelor & 200.000 & 6,79 \\
\hline & b. Pencucian dan pelayuan & 320.000 & 10,87 \\
\hline & c. Sortasi dan Penimbangan daun kelor Sesudah & 320.000 & 10,87 \\
\hline & Sortasi & & \\
\hline & d. Pengeringan dan Penghalusan & 400.000 & 13,59 \\
\hline & e. Pengemasan Tahap 1 & 520.000 & 17,67 \\
\hline & p. Pengemasan Tahap 2 & 320.000 & 10,87 \\
\hline & 3. Bunga Modal Variabel & 14.645 & 0,50 \\
\hline C & Biaya Variabel Total & 2.943.645 & 100,00 \\
\hline D & Biaya Total & 3.048.816 & \\
\hline $\mathbf{E}$ & Produksi & 5.000 & \\
\hline $\mathbf{F}$ & Harga & 1.100 & \\
\hline G & Penerimaan & $\mathbf{5 . 5 0 0 . 0 0 0}$ & \\
\hline $\mathbf{H}$ & Keuntungan & 2.451.183,95 & \\
\hline
\end{tabular}


Pada Tabel diatas bisa dilihat bahwa analisis agroindustri teh celup daun kelor yang besar mengeluarkan biaya adalah biaya variabel total $\mathrm{Rp}$ 2.943.645.karena pada biaya variabel yang besar mengeluarkan biaya adalah pada upah tenaga kerja. Biaya variabel adalah biaya yang besar kecilnya bergantung pada besar kecilnya volume produksi, dan sifatnya habis dalam satu kali proses produksi.

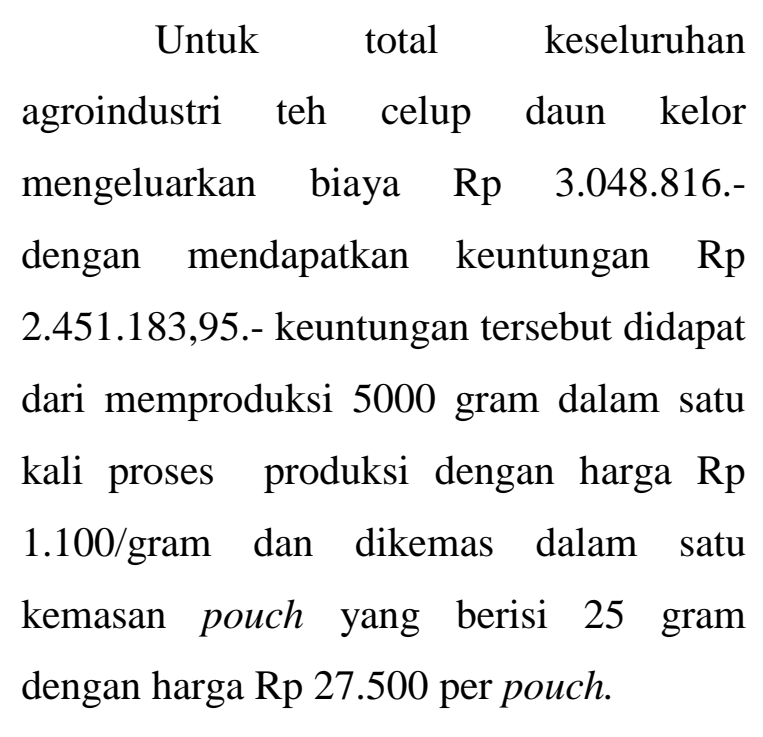

\section{Rentabilitas Pada Agroindustri Teh Celup Daun Kelor}

Rentabilitas digunakan untuk melihat kemampuan agroindustri teh celup daun kelor dalam menghasilkan laba dari modal (biaya) yang digunakan dalam periode tertentu. Dalam penelitian ini dihitung dalam satu kali proses produksi. Berdasrkan hasil perhitungan diketahui, bahwa pendapatan atau keuntungan yang diperoleh dari agroindustri teh celup daun kelor per satu kali proses produksi adalah sebesar Rp 2.451.183,95.- dan biaya total (modal) yang dikeluarkan dalam agroindustriteh celup daun kelor per satu kali proses produksi adalah Rp 3.048.816.maka dengan demikian dapat dihitung nilai retabilitasnya sebagai berikut :

$$
R=\frac{L}{M} \times 100 \%
$$

$$
\begin{aligned}
\mathrm{R} & =\frac{2.451 \cdot 183,95}{3.048 .816} \times 100 \% \\
\mathrm{R} & =80,40 \%
\end{aligned}
$$

Hasil perhitungan menunjukkan bahwa nilai rentabilitas agroindustri teh celup daun kelor di Desa Ciheras 80,40\% dengan demikian agroindustri tersebut mampu menghasilkan laba 80,40\% dari modal yang dikeluarkan dalam satu kali proses produksi.

Menurut Prabowo (2018) dalam penelitiannya mengungkapkan bahwa rentabilitas modal sendiri rata-rata 16,015\% (>15\%) maka kinerja keuangan PT. Gudang Garam Tbk dalam keadaan baik, yang artinya dengan modal sendirinya PT. Gudang Garam Tbk mampu menghasilkan keuntungan. Dengan kata lain dapatlah dikatakan bahwa PT. Gudang Garam Tbk telah mampu memanfaatkan modal sendiri perusahaan secara efisien. 


\section{Tenaga Kerja}

Tenaga Kerja yang dibutuhkan dalam agroindustri teh celup daun kelor adalah untuk pengolahan mulai dari proses persiapan bahan baku daun kelor sampai pada proses pengemasan, dimana tenaga kerja yang digunakan adalah sebanyak 6 orang dengan 52 hari orang kerja (HOK) dan upah tenaga kerja yang dikeluarkan $\mathrm{Rp}$ 40.000.- per orang sehingga biaya yang dikeluarkan Rp 2.080,000.- per satu kali proses produksi. Zamrowi dalam Vera (2013), menyatakan Penambahan bahan baku dan alat produksi tersebut akan membutuhkan tambahan tenaga kerja. Jadi, industri kecil dan menengah furniture kayu akan menambah tenaga kerja pada saat bahan baku dan alat produksi yang dibeli dari modal kerja tersebut bertambah dan semakin besar modal yang ditanamkan akan semakin besar pula permintaan tenaga kerja.

Tenaga Kerja yang terlibat adalah penduduk Desa Ciheras yang berada pada usia produktif, yaitu 15 sampai 64 tahun dan dapat diketahui tingkat penyerapan tenaga kerja pada agroindustri teh celup daun kelor yaitu sebesar 0,18\%. Angkatan tersebut diperoleh dari perbandingan antara jumlah tenaga kerja yang diserap sebanyak 6 orang, dengan jumlah penduduk usia kerja sebanyak 3.385 orang dikalikan dengan $100 \%$.

\section{KESIMPULAN dan SARAN}

Kesimpulan

Berdasarkan hasil penelitian dan pembahasan, maka dapat ditarik kesimpulan sebagai berikut : 1)Besarnya biaya yang dikeluarkan PT. Lentra Bumi Nusantara pada agroindustri teh celup daun kelor dalam satu kali proses produksi adalah $\quad \mathrm{Rp}$ 3.048.816.- besarnya penerimaan yang diperoleh Rp 5.500.000.besarnya pendapatan pada agroindustri teh celup daun kelor adalah $\operatorname{Rp} 2.451 .183,95$.2) Besarnya nilai rentabilitas agroindustri teh celup daun kelor di Desa Ciheras Kecamatan cipatujah 80,40 \% . 3) Jumlah tenaga kerja yang diserap pada agroindustri teh celup daun kelor dari lingkungan Desa Ciheras dalam satu kali proses produksi adalah sebanyak 6 orang dengan penyerapan tenaga kerja sebesar 0,18 persen.

\section{Saran}

Berdasarkan pembahasan dan kesimpulan, disarankan perusahaan meningkatkan skala usaha dan keuntungannya dengan cara meningkatkan produksi teh celup daun kelor dan memperluas penanaman daun kelor guna 
untuk dapat menyerap tenaga kerja yang lebih banyak.

\section{DAFTAR PUSTAKA}

Direktorat Jenderal Perkebunan. 2014. Statistik Perkebunan Indonesia. Jakarta (ID): Kementrian Pertanian Indonesia.

Harahap. 2008. Analisis Kritis atas Laporan Keuangan. Edisi Kesatu. PT. Raja Grafindo Persada. Jakarta

Kasolo, J, N., Bimeya, GS., Ojok, L., Ochieng, J., Okwal-okeng, J, W. 2010. Ms Analysis and In Vitro Screening of Four Species of Mucuna. Asian Journal of Pharmaceutical and Clinical Research (5): 239-243.

Khan N, Afaq F, Saleem M, Ahmad N, Mukthar H. 2005. Targeting multiple signaling pathways by green tea polyphenol (-)Epigallocatechin-3-gallate.

American Association for Cancer Research (5) 2500-2505.

Lasut. Thelbic. 2015. Judul jurnal. ( jurnal EMBA, issn : 2303-1174 . Vol. 3 No. 1). Universitas Sam Ratulangi. Manado

Moore RJ, Jackson KG, Minihane AM. 2009. Green tea (Camellia sinensis) catechins and vascular function. British Journal of Nutrition (102) 1780 - 1802.

Mulyani, S. 2010. Metodologi Penelitian Angkatan Kerja. Edisi Pertama. USU Press. Medan.

Mulyani, S. 2010. Metodologi Penelitian Angkatan Kerja. Edisi Pertama. USU Press. Medan.
Mineral Composition Of Leaf Extracts Of Moringa Oleifera Lam. From Nsukka, South-Eastern Nigeria. Journal of pharmacy and biological sciences. Volume 9, issue 3.

Prabowo Budhi 2018. Analisis Rasio Rentabilitas Untuk menilai kinerja keuangan pada PT. Gudang Garam, Tbk 1. Universitas Pemulang.

Rahardja. P dan Manurung, M. 2008. Pengantar Ilmu Ekonomi (Mikroekonomi dan Makroekonomi). Fakultas Ekonomi Universitas Indonesia. Depok

Rahim dan Hastuti. 2008. Pengantar Bisnis Modern. PT Bumi Aksara. Jakarta.

Sashidhara, K, V, J, N., Rosaiah, E., Tyagi, R., Shukla, R., Raghubir, SM., Rajendrn. 2009. Rare Dipeptide and Urea Derivaties from Roots of Moringa oliefera as Potential aAnti-inflammatory and Antinociceptive Agents, European Journal of Medicinal Chemistry (44): 432-436.

Soekartawi. 2008. Analisis Usahatani. UI Press. Jakarta.

Vera H.S. 2013. Analisis Penyerapan Tenaga Pada Industri Kecil dan Menengah. Diponegoro Journal Of Economics. 4(2):1-9

Wilcoz, J. dan Subramanian, 1997. Expression of Multiple Isoforms of Nitric Oxide Synthase in Normal and Atherosclorotic Vessel. Journal Arteroscler Thormb Vasc Biology (17): 2479-2488. 